\title{
Ethnobotany and conservation of indigenous edible fruit plants in South Aceh, Indonesia
}

\author{
ADI BEJO SUWARDI ${ }^{1, \vartheta}$, ZIDNI ILMAN NAVIA ${ }^{2}$, TISNA HARMAWAN ${ }^{3}$, SYAMSUARDI $^{4}$, \\ ERIZAL MUKHTAR ${ }^{4}$ \\ ${ }^{1}$ Department of Biology Education, Faculty of Teacher Training and Education, Universitas Samudra. Jl, Meurandeh, Langsa 24416, Aceh, Indonesia. \\ Tel.: +62-641-426535, `email: adi.bsw@gmail.com \\ ${ }^{2}$ Department of Biology, Faculty of Engineering, Universitas Samudra. J1, Meurandeh, Langsa 24416, Aceh, Indonesia \\ ${ }^{3}$ Department of Chemistry, Faculty of Engineering, Universitas Samudra. J1, Meurandeh, Langsa 24416, Aceh, Indonesia \\ ${ }^{4}$ Department of Biology, Faculty of Mathematics and Sciences, Universitas Andalas. J1. Unand, Limau Manis, Padang 25163, West Sumatra, Indonesia
}

Manuscript received: 8 November 2019. Revision accepted: 8 April 2020

\begin{abstract}
Suwardi AB, Navia ZI, Harmawan T, Syamsuardi, Mukhtar E. 2020. Ethnobotany and conservation of indigenous edible fruit plants in South Aceh, Indonesia. Biodiversitas 21: 1850-1860. The traditional knowledge system is immensely important in the context of plant resource conservation, utilization, and environmental management. The objectives of this study, therefore, were to document local knowledge on the diversity, utilization and sustainable management of indigenous fruit yielding species in the South Aceh region of Indonesia. This research was based on extensive field surveys, plant collection, and interviews with the local people, and a total of 56 indigenous edible fruit species belonging to 24 families were identified. Furthermore, the recognized varieties have numerous applications and serve multiple use categories. For example, they have been adopted as food (56 species), by medicine (16 species), construction materials (14 species), furniture (13 species) and firewood (12 species). These indigenous edible fruits are mostly used in the treatment of cough, stomach ache, diarrhea, fever, and digestive problems, and the following species are commonly traded in traditional markets Durio zibethinus, Garcinia mangostana, Mangifera indica, Mangifera foetida, Mangifera odorata, Baccaurea macrophylla, and Baccaurea lanceolata. The agricultural expansion activities in South Aceh region are assumed to present significant threats to the sustainability of indigenous edible fruit species. Conservation of indigenous fruit plants can be performed through the preservation of traditional knowledge and the promotion and domestication of indigenous fruit plant species.
\end{abstract}

Keywords: Ethnobotany, indigenous edible fruit, traditional uses, South Aceh

\section{INTRODUCTION}

Sumatra Island is considered to be one of the regions with high biodiversity and endemicity (Ismaini et al. 2015). Of the five major islands in Indonesia, the tropical mountain forests of this island support plant communities of higher diversity, compared to other parts of the world (Whitten et al. 1997), supporting the third-largest number of endemic species in specific taxa (Roos et al. 2004). Furthermore, Sumatra is regarded as a hotspot of tropical fruit plant diversity, with a total of 148 recorded species (Uji 2004), which are classified into at least four genera belonging to four families of high economic value. These genera are Mangifera (Anacardiaceae), Garcinia (Clusiaceae), Nephelium (Sapindaceae) and Durio (Malvaceae) (Winarno 2000). Watson (1984) recorded nine varieties of rambutan (Nephelium lappaceum) in Aceh province. Rahmawati and Hayati (2013) have also identified as many as twenty varieties of banana (Musa paradisiaca) in Aceh Besar District, while a total of 31 durian (Durio sp.) species were recognized in Indonesia, with one species endemic to Sumatra (Yap et al. 1995; Navia and Chikmawati 2015). In addition, 35 species of the genus Baccaurea, which grow wild on numerous islands in Indonesia, including Sumatra, have also been identified (Gunawan et al. 2016).
These indigenous fruit species play a significant role in the daily life of people living in developing countries, due to their ability to serve as sustainable resources (Mwema et al. 2012; Mabaya et al. 2014; Khruomo and Deb 2018). These major forest products provide an alternative source of nutrition (Muok et al. 2001; Suwardi et al. 2020), including essential vitamins, minerals, and fiber required to maintain health. Furthermore, fruits also influence a wide range of agricultural systems as a source of wild food, which plays an important socio-economic role in medicine, shelter, fibers and traditional ceremonies (FAO 1999). There is also a high potential to elevate the economic situation as a source of cash income, which provides food security to the indigenous people (Deb et al. 2013). Worldwide, locals tend to store extensive knowledge related to the use of local plants as food and other specific applications (Sundriyal et al. 1998). Therefore, the adoption of a large number of wildlife species to satisfy varied needs primarily requires the prevalence of vegetation diversity in the specific region (Katewa 2003).

Rural communities in the South Aceh region have $q$ tradition of collecting and utilizing several species of edible wild plants. Through this practice, the locals have acquired substantial traditional knowledge of edible properties and nutritional significance of local biodiversity which may be adopted in combat against food insecurity and malnutrition 
(Johns et al. 1996). This wisdom has been transmitted through generations (Pilgrim et al. 2008), although, modernization, has been implicated in the reduction of knowledge as well as the use of biodiversity (Ong et al. 2012; Wiryono et al. 2017). Many earlier studies have demonstrated the inability of older generations to transfer traditional knowledge to the young (Quinlan and Quinlan 2007; Sousa et al. 2012; Saynez-Vaquest et al. 2016), leading to alienation of the younger generation from their immediate environment and the ultimate loss of information related to nature. In addition, the presence of wild edible fruit plants is also threatened by the expansion of the agricultural sector (Balemie and Kebebew 2006; Amente 2017). The objectives of this study, therefore, were to document local knowledge on the diversity, utilization and sustainable management of indigenous fruit yielding species in the South Aceh region of Indonesia.

\section{MATERIALS AND METHODS}

\section{Study area}

The topography of South Aceh District is highly varied, ranging from lowlands to hills with very steep slopes. The total land area is $4,173.82 \mathrm{~km}^{2}$, which extends from north to west, with an altitude of about 2 to $74 \mathrm{~km}^{2}$. This region experiences a dry season from January to July and rainy season from August to December. Rainfall ranges from 1,677 to $4,552 \mathrm{~mm}$ per year, which is distributed into 101-225 rainy days per year. The total population of South Aceh is 230,254 comprising of three indigenous tribes, namely Aceh (60\%), Aneuk Jamee (30\%) and Kluet (10\%). This District has 18 sub-districts, which are divided into 260 villages. The present study was conducted in a total of six villages belonging to two subdistricts, namely Kluet Selatan and Kluet Tengah, selecting three villages from each of them. The villages are Pasi Lembang, Ujung Pandang and Rantau Binuang of Kluet Selatan and Koto, Lawe Melang, and Malaka of Kluet Tengah (Figure 1).

\section{Data collection}

The information on edible fruit species was acquired through participatory observations and semi-structured, indepth interviews, conducted with the informants, based on the provided by Alexiades and Sheldon (1996). The study involved a total of 120 informants (20 persons from each village), selected on the basis of the intended snowball sampling method, having different background characteristics such as sex, age group, marital status and educational levels (Table 1).

The voucher specimens of all indigenous fruit plants were collected, along with the recording of their local names, parts used, habits in the field, quantity harvesting, price, and additional information on trade. Furthermore, the botanical identification was performed at the Herbarium of Andalas University, Padang, West Sumatra. The botanical names were updated as per The Plant List (www.theplantlist.org) and the International Plant Name Index (www.ipni.org).

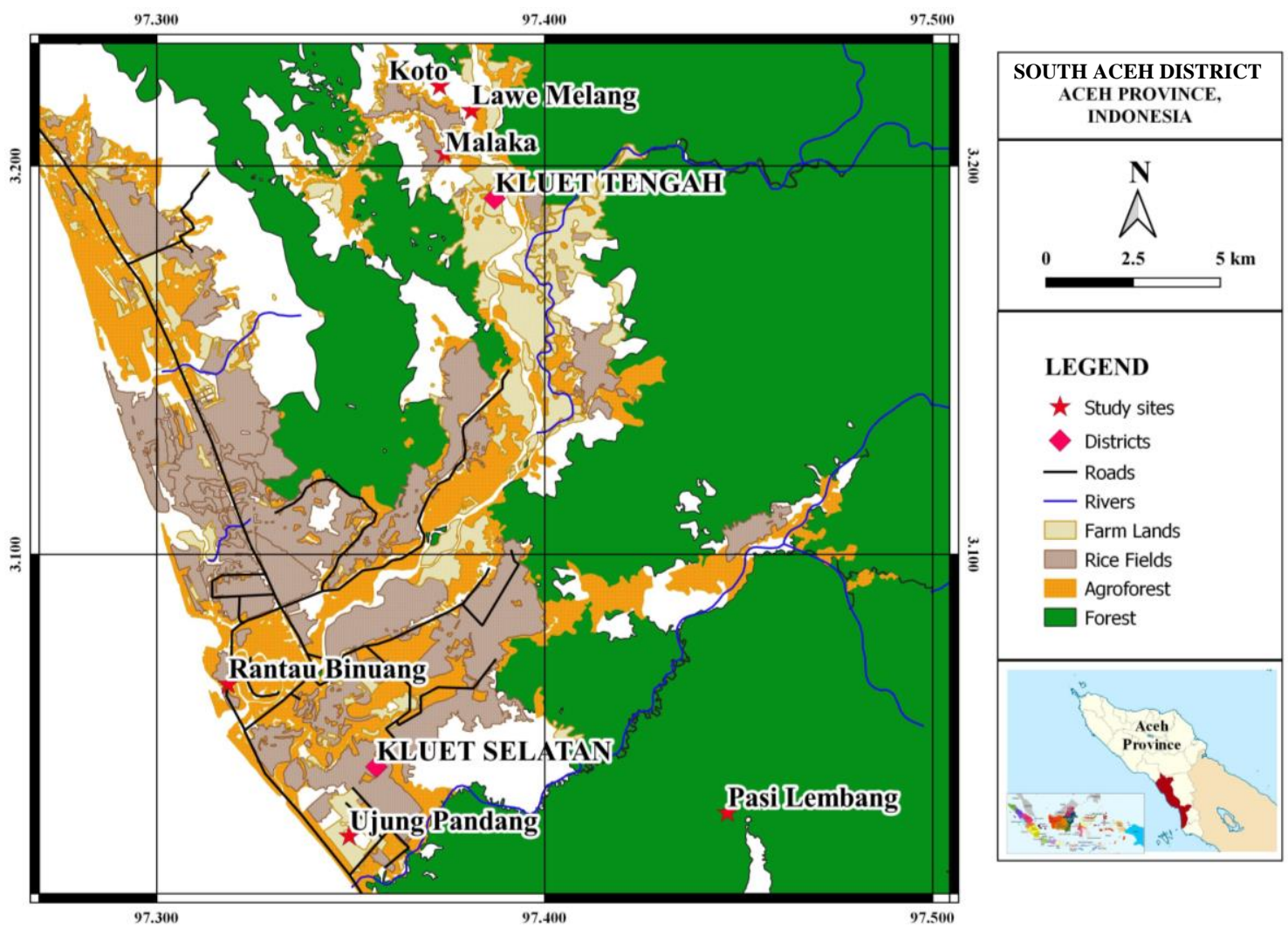

Figure 1. Map of South Aceh District, Aceh Province, Indonesia, showing the study locations 
Table 1. Background characteristics of respondents

\begin{tabular}{lccc}
\hline Items & Alternatives & $\begin{array}{c}\text { Number } \\
\text { (Total = 120) }\end{array}$ & Percentage \\
\hline Sex & Male & 52 & 43.3 \\
Age & Female & 68 & 56.7 \\
& $26-35$ & 25 & 20.8 \\
& $36-45$ & 35 & 29.2 \\
Education status & $46-55$ & 38 & 31.7 \\
& $>55$ & 22 & 18.3 \\
& Elementary & 52 & 43.3 \\
& School & & \\
& Secondary & 39 & 32.5 \\
& School & & \\
Marital status & High School & 18 & 15.0 \\
& University & 11 & 9.2 \\
& Single & 28 & 23.3 \\
& Married & 80 & 66.7 \\
& Widowed & 12 & 10.0 \\
\hline
\end{tabular}

\section{Data analysis}

Two quantitative parameters, namely informant consensus factor (ICF) and relative frequency of citation (RCF) were used to analyze the qualitative ethnobotanical information collected from informants, as shown below:

\section{Informant consensus factor (ICF)}

An informant consensus factor (ICF) is used to assess the homogeneity of local knowledge, which is calculated using the formula of Cornara et al. (2014) as follows:

$$
I C F=\frac{[N u r-N s]}{\lceil N u r-1\rceil}
$$

Where; Nur is the number of reports of usefulness for each category, and Ns is the number of species used by all informants for certain categories.

ICF values range from 0 to 1 . A high ICF value (close to 1) indicates that relatively few plant species are used by a large proportion of the informants while a low value indicates the disagreement of the informants on the use of plant species in the different categories.

\section{Relative frequency of citation (RFC)}

Relative frequency of citation (RFC) is a quantitative index that provides the local importance of the investigated species, which is calculated using the following the formula described by Tardiõ et al (2008):

$$
R F C=\frac{F C}{N}
$$

Where; $F C$ is the frequency of citation and $N$ is the total number of respondents who participated in interviews. The RFC value ranges from 0 (where none of the informants mentions the plant as being useful) to 1 (where each informant reports the plant as being useful).

\section{RESULTS AND DISCUSSION}

\section{Diversity of indigenous edible fruit plants and their uses}

The results show that the flora of the study area is rich in useful species, which includes a total of 56 indigenous fruit plant species, classified in 34 genera and 24 families. The average number of species identified by each age group of the respondent ranged from $10.5 \pm 2.11$ (26-35 years) to $32.22 \pm 4.01$ (> 55 years). Respondents of age group 36-45 years identified $20.3 \pm 2.26$ species, while of $45-55$ years identified $25.7 \pm 3.16$ species. Besides indicating a really large variation between age categories, this also reflects a direct relation between the age of respondents and the number of species known. Some plants were recognized by respondents, of all ages, and such widely known species include langsat (Lansium parasiticum), rambai (Baccaurea motleyana), durian (Durio zibethinus), rambutan (Nephelium lappaceum), and sirsak (Annona muricata). On the contrary, some other species were familiar to less than $20 \%$ of the respondents. berangan bukit (Castanopsis costata), tampoi (Baccaurea pyriformis), durian burung (Durio acutifolius), Pala hutan (Myristica elliptica), beri hutan (Rubus buergeri), (Elaeocarpus beccarii), simpur (Dillenia indica), balek angin (Mallotus philippensis), kedondong (Spondias dulcis), kuranji hutan (Dialium platysepalum), and jentik (Baccaurea polyneura) are some examples for such less known species. This study supports the earlier finding that knowledge of the use of local plants is dependent on the participants' age (Begossi et al. 2002).

In addition to edible purposes, the fruit yielding plants were also used for various other purposes like medicinal, firewood, construction, furniture making, and fodder. The number of species used for each of these purposes with the corresponding ICF values is shown in Table 2.

The highest informant consensus values were obtained for food and firewood (ICF $=0.99$ ), followed by medicinal plants, construction material, and furniture $(\mathrm{ICF}=0.98)$ while it was least for the plants used for fodder (ICF = 0.97). The highest ICF value of food reveals that indigenous fruit plants play an important role in the sustenance of the people of the region. The various fruit plants provide essential vitamins and minerals for a healthy life. In addition, indigenous fruit trees also provide economic benefits for people in the South Aceh region. The use of reported plants during this investigation is similar to previous studies where plants are used mainly as food ( $\mathrm{Li}$ et al. 2015; Aryal et al. 2018; Rana et al. 2019). Miranda et al. (2011) and Poderoso et al. (2012) identified the primary relationship between the performance of a plant resource and a specific food resource. A higher number of plants used by local people for firewood indicate their dependence on available plant resources for energy. Most rural communities in the South Aceh region are still using wood for cooking purposes. This is consistent with the report by Dwiprabowo (2010) and Munawaroh et al. (2011) that firewood is widely used as an energy source by households and domestic food industries in rural areas. 
Table 2. Use-wise number of species and their Informant consensus factor (ICF)

\begin{tabular}{lccc}
\hline Category of use & Cited plants & Citations & ICF \\
\hline Food & 54 & 4,896 & 0.99 \\
Medicinal & 16 & 639 & 0.98 \\
Firewood & 12 & 1,376 & 0.99 \\
Construction material & 14 & 630 & 0.98 \\
Furniture & 13 & 546 & 0.98 \\
Fodder & 8 & 224 & 0.97 \\
\hline
\end{tabular}

\section{Plants used as food}

Many species of the indigenous edible fruit plants used by the local people of South Aceh region are easily recognized in the surroundings, including Mango $(M$. indica), Mangosteen (G. mangostana), Guava (P. guajava), Soursop (A. muricata) and Rose apple (S. aqueum). Furthermore, numerous wild species are less preferred by the community, due to the conservation of acidic characteristics, spicy tastes, and also the presentation is relatively small sizes, although some are also highly favored, including kepong (B. lanceolata), bacang ( $M$. foetida) and durian daun (D. oxleyanus).

Based on RFC values, indigenous fruit plants are commonly found as cultivated plants to have the highest RFC values $(\mathrm{RFC}=1,00)$. A total of eighteen (18) species, namely A. occidentale, A. muricata, A. integer, A. bilimbi, A. carambola, B. motleyana, C. aurantifolia, C. maxima, D. longan, D. zibethinus, G. mangostana, L. parasiticum, M. foetida, M. indica, M. zapota, $N$. lappaceum, $P$. guajava, and S. aqueum (1.00 or $100 \%)$ which is recognized by all respondents. As many as 16 fruit plant species are recognized only by less than $50 \%$ of respondents with an RFC value of 0.01-0.50. Plants with low RFC value, some are difficult to find in the surrounding villages, for example, B. brevipes, B. lanceolata, and $M$. elliptica. This study is consistent with Silalahi et al. (2018) that plants difficult to find in the surrounding area of community residences are generally not well known and have low RFC values.

\section{Plants used as traditional medicines}

Local people in the study region, particularly individuals living close to the forest areas, tend to use the fruit-producing plants as traditional medicines for the treatment of various illnesses (Table 4).

As a result of the study, 16 of the 56 species of fruit plants used by local people in the South Aceh region as traditional medicines. Plant parts used among Aceh, Kluet, and Aneuk Jamee tribes to treat various illnesses were primarily leaves $(7 \%)$, fruits $(2 \%)$, barks $(1 \%)$, and roots $(1 \%)$. The majority of tribal communities in the world use leaves for herbal medicine (Ullah et al. 2013; Yabesh et al. 2014; Prabhu et al. 2014; Vijayakumar et al. 2015). The leaves were mostly used because they are very easily collected than flowers and fruits, etc. (Giday et al. 2009). The most commonly used ethnomedicine plant remedies were coughs (5 plant species), dysentery, diarrhea, fever (4 plant species), swelling, boils and pain (4 plant species), stomach pain (2 plant species), toothache and anthelmintic (2 plant species each), and rheumatism, colds, headache, hypertension, dengue fever, bleeding gums and pimples (1 plant species each).

Local people in the South Aceh region apply more than one plant species in the management of disease from ancient times, and most tend to possess one or more ethnomedicinal purposes. In addition, traditional medicine is widely adopted in the treatment of mild ailments, including coughs, stomach ache, diarrhea, fever, and other digestive problems, which have collectively been affiliated with unhygienic conditions, unhealthy food quality, and the deprivation of clean drinking water. The locals have no proper access to timely and appropriate modern treatment for prevalent diseases, hence the steady dependence on readily accessible traditional herbal medicines. Based on some studies, a few species contain bioactive compounds with medically applicable features (Pedraza-Chaverri et al. 2008; Abbasi et al. 2013; Bunawan and Dusik 2013; Silalahi et al. 2015; Mohanty and Pradhan 2015; Murmu et al. 2016; Wiryono et al. 2017; Handayani 2018; Suwardi et al. 2018; Sanjayrao and Sanjay 2019; Suwardi et al. $2019 b$ ). These preparations are generally produced in the form of infusions, stews, paste, juices, and dry powders, on the basis of dosages that are not standardized (Hazarika et al. 2012). Therefore, it is necessary to establish the safety, effectiveness, and preservation of these highly valuable indigenous edible fruits, and also critically study the claimed therapeutic values of reported species.

A total of 56 species of fruit plants are used as food by the local communities of the study area (Table 3 ).

\section{Trade of indigenous fruit plant products}

Rural communities in South Aceh are collecting indigenous fruit plants for sale in the traditional market, or some of them have been sold along the roadsides around the villages. The fruit was mostly harvested from the remaining forest patches, home gardens, and crop fields. Species, trade part, average quantity and market price of indigenous fruit plants were sold by rural communities in South Aceh is shown in Table 5.

During our survey at the traditional market in some subdistricts around the study site, we noticed mangoes $(M$. indica), durian (D. zibethinus), kuwini (M. odorata), longan (D. longan), pummelo (C. maxima), guava ( $P$. guajava), and bilimbi (A. carambola) for sale, but according to traders, wild fruit like tampoi (B. brevipes), tampoi (B. lanceolata), jentik ( $B$. polyneura), and rukam ( $F$. rukam) were occasionally marketed. These wild varieties possess a similar aroma, flavor, and taste with cultivated fruits (Suwardi et al. 2019a). Most indigenous fruit plants play a significant role in enhancing the health and ensuring food security in rural communities of South Aceh region. These are also known to serve as a feasible source of vitamins and minerals essential for maintaining good health (Saka et al. 1994) and improving the guarantee of food (Mojeremane and Tshwenyane 2004). Furthermore, the findings indicate that as many as $68 \%$ of all respondents sold the indigenous forms, which provides possible benefits and boost household income. However, of all the participants selling indigenous edible fruits, about $48 \%$ receive less than 20,000,000 Indonesian Rupiah (IDR) per year ( $1 \mathrm{USD}=14,000 \mathrm{IDR}$ at the moment of this study), while approximately $36 \%$ earn between IDR 20,000,000 and 30,000,000 per year. 
Tabel 3. Indigenous fruit plants used as food

\begin{tabular}{|c|c|c|c|c|c|}
\hline Botanical Name & Family & Common name & Part use & Use & RFC \\
\hline Aleurites moluccana (L.) Wild & Euphorbiaceae & Candlenut, kemiri & Fruit & The nut is often cooked, while the chewed seeds are used as a substitute for soap & 0.93 \\
\hline Anacardium occidentale $\mathrm{L}$. & Anacardiaceae & Cashew nut, jambu mete & Fruit & The fruit is consumed raw & 1.00 \\
\hline Annona muricata $\mathrm{L}$. & Annonaceae & Soursop, sirsak & Fruit & The fruit is consumed raw & 1.00 \\
\hline Annona squamosa $\mathrm{L}$. & Annonaceae & Sugar apple, buah nona & Fruit & The fruit is consumed raw & 0.73 \\
\hline Archidendron jiringa (Jack) Neil. & Leguminosae & Jengkol & $\begin{array}{l}\text { Fruit, young } \\
\text { shoots }\end{array}$ & $\begin{array}{l}\text { Fresh fruit is eaten as raw vegetables or made into "rendang," while the young } \\
\text { shoots are consumed as a vegetable }\end{array}$ & 0.82 \\
\hline Artocarpus altilis (Parkinson) Forsberg & Moraceae & Bread fruit, sukun & Fruit, seed & $\begin{array}{l}\text { Fresh and ripened fruit are taken raw, while the immature type is used as } \\
\text { vegetables. Moreover, the seeds are eaten after boiling, baking, roasting or frying, } \\
\text { while the immature seeded fruit is cooked as a vegetable with coconut milk }\end{array}$ & 0.73 \\
\hline $\begin{array}{l}\text { Artocarpus camansi (Parkinson) } \\
\text { Fosberg }\end{array}$ & Moraceae & Breadnut, kluwih & Fruit & $\begin{array}{l}\text { Both fresh and ripened fruits are eaten raw, while the immature forms are used } \\
\text { as vegetables }\end{array}$ & 0.85 \\
\hline Artocarpus integer (Thunb.) Merr. & Moraceae & Cempedak & Fruit, seed & $\begin{array}{l}\text { The ripened fruit is consumed raw, while the fresh forms are used as vegetables, } \\
\text { and the seed is eaten after boiling, baking, roasting or frying }\end{array}$ & 1.00 \\
\hline Artocarpus elasticus Reinw. ex Blume & Moraceae & Terap & Fruit, seed & Fruits are ingested raw, while the seeds require initial roasting & 0.63 \\
\hline Averrhoa bilimbi $\mathrm{L}$. & Oxalidaceae & Bilimbi, belimbing wuluh & Fruit & The fruit is dried and used as a cooking spice & 1.00 \\
\hline Averrhoa carambola $\mathrm{L}$. & Oxalidaceae & Carambola, belimbing & Fruit & This is consumed raw & 1.00 \\
\hline Baccaurea brevipes Hook.f. & Phyllantaceae & Tampoi hutan & Fruit & This form is taken raw & 0.21 \\
\hline $\begin{array}{l}\text { Baccaurea macrophylla (Mull. Arg) } \\
\text { Mull. Arg }\end{array}$ & Phyllantaceae & Lang khae, tampoi & Fruit & The fruit is eaten raw & 0.27 \\
\hline Baccaurea lanceolata (Miq.) Mull.Arg & Phyllantaceae & Tampoi, kepong & Fruit & This variety is ingested raw & 0.61 \\
\hline $\begin{array}{l}\text { Baccaurea motleyana (Müll.Arg.) } \\
\text { Müll.Arg. }\end{array}$ & Phyllantaceae & Rambai & Fruit & $\begin{array}{l}\text { The fruit is eaten raw, made into drinks, and sometimes pickled to be served } \\
\text { with curries }\end{array}$ & 1.00 \\
\hline Baccaurea polyneura Hook.f. & Phyllantaceae & Jentik & Fruit & This variety is consumed raw & 0.18 \\
\hline Baccaurea pyriformis Gage & Phyllantaceae & Tampoi & Fruit & The fruit is eaten raw & 0.10 \\
\hline Bischofia javanica Blume & Euphorbiaceae & Java cedar & Fruit & This is also ingested raw & 0.54 \\
\hline Castanopsis costata (Blume) A.DC. & Anacardiaceae & Berangan bukit & Fruit & The nuts are edible & 0.09 \\
\hline $\begin{array}{l}\text { Citrus aurantifolia (Christm. \& } \\
\text { Panzer) Swingle }\end{array}$ & Rutaceae & Lime, jeruk sambal & Fruit & The fruit is eaten raw & 1.00 \\
\hline Citrus maxima (Burm.) Merr & Rutaceae & Pummelo, jeruk & Fruit & The fruit is eaten raw & 1.00 \\
\hline Dialium platysepalum Baker & Fabaceae & Kuranji hutan & Fruit & The fruit is eaten raw & 0.18 \\
\hline Dillenia indica $\mathrm{L}$. & Dilleniaceae & Simpoh, simpur & Fruit & The juicy fruit is usually used in curries, preserves, and drinks & 0.13 \\
\hline Dimocarpus longan Lour. & Sapindaceae & Longan, lengkeng & Fruit & The fruit is eaten raw & 1.00 \\
\hline Durio griffithii (Mast.) Bakh & Malvaceae & Durian hutan & Fruit & The fruit is eaten raw & 0.10 \\
\hline Durio oxleyanus Griff. & Malvaceae & Durian daun & Fruit & The fruit is eaten raw & 0.73 \\
\hline Durio zibethinus Murr. & Malvaceae & Durian & Fruit, seed & $\begin{array}{l}\text { The fruit is eaten raw or made into "Dodol durian," while the seeds are } \\
\text { consumed after boiling, baking, roasting or frying }\end{array}$ & 1.00 \\
\hline
\end{tabular}


Elaeocarpus beccarii Aug.DC.

Flacourtia rukam Zoll. \& Moritzi

Garcinia mangostana L.

Garcinia parvifolia (Miq.) Miq.

Garcinia xanthochymus Hook.f. ex

T.Anderson

Lansium parasiticum (Osbeck)

K.C.Sahni \& Bennet

Leea rubra Blume

Litsea cubeba (Lour.) Pers.

Lithocarpus wallichianus (Lindl. ex

Hance) Rehder

Mallotus philippensis (Lam.) Müll.Arg. Mangifera caesia Jack.

Mangifera foetida Lour.

Mangifera indica $\mathrm{L}$.

Mangifera odorata Griff.

Manilkara kauki L.

Manilkara zapota (L.) P. van Royen

Monocarpia euneura Miq.

Myristica elliptica Wall

Myristica fragrans Houtt

Nephelium lappaceum L.

Passiflora foetida $\mathrm{L}$.

Physalis minima $\mathrm{L}$

Psidium guajava Blanco

Rubus buergeri $\mathrm{Mi}$

Salacca acehensis Mogea \& Zumaidar

Spondias dulcis Parkinson

Syzygium aqueum (Burm. f.) Alston

Syzygium densiflorum Wall. ex Wight

\& Arn.

Syzygium samarangense (Blume) Merr. Myrtaceae
Flacourtiaceae

Clusiaceae

Medan

Clusiacea

Meliaceae

Leeaceae

Lauraceae

Euphorbiaceae

Anacardiaceae

Anacardiaceae

Anacardiaceae

Anacardiaceae

Sapotaceae

Sapotaceae

Annonaceae

Myristicaceae

Myristicaceae

Sapindaceae

Passifloraceae

Solanaceae

Myrtaceae

Rosaceae

Rosaceae

Anacardiaceae

Myrtaceae

Myrtaceae
Mangosteen, manggis

Manggis hutan

Asam gelugur

Lansat

Red tree-vine

Medang

Mempening

Frui

Fruit

Fruit

Fruit

Fruit

Fruit

Seed

Balek angin

Binjai

Bacang

Mango, mangga

Kuwini

Caqui, sawo kecik

Sawo

Not know

Pala hutan

Rambutan

Goat-scented

passionflower, rambusa

Sunberry, ciplukan

Guava, jambu biji

Beri hutan

Salak

Golden apple,

kedondong

Rose apple, jambu air

Jambu hutan

Java apple, jambu air
The fruit is eaten raw

The fruit is eaten raw

The fruit is eaten raw

The fruit is eaten raw

The fruit is eaten raw, cooked and also as a flavoring in other foods

0.7

The fruit is eaten raw

The fruit is consumed to treat dysentery

The fruit is consumed as a spice ingredient

The seed is usually cooked before eating, although they are sometimes ingested

The seed is usually cooked before consumption

The fruit is eaten raw

The fruit is eaten raw

The fruit is eaten raw

The fruit is eaten raw

The fruit is eaten raw

The fruit is eaten raw

The fruit is eaten raw

The fruit is used as a spice

The fruit is used as a spice

The fruit is eaten raw

The fruit is eaten raw

The fruit is eaten raw

The fruit is eaten raw or made into a drink

The fruit is eaten raw

The fruit is eaten raw

The fruit is eaten raw

The fruit is eaten raw

The fruit is eaten raw 
Table 4. Indigenous edible fruit plants used as traditional medicines

\begin{tabular}{|c|c|c|c|c|c|}
\hline Botanical Name & Family & Common name & Part use & Diseases treated & RFC \\
\hline Aleurites moluccana & Euphorbiaceae & Candlenut, Kemiri & Bark & Dysentery & 0.19 \\
\hline Anacardium occidentale & Anacardiaceae & Cashew nut, Jambu mete & Leave & Toothache & 0.09 \\
\hline Annona muricata & Annonaceae & Soursop, Sirsak & $\begin{array}{l}\text { Leave } \\
\text { Fruit }\end{array}$ & $\begin{array}{l}\text { Rheumatism, coughs, and colds } \\
\text { Fever, headache, and hypertension }\end{array}$ & 0.90 \\
\hline Archidendron jiringa & Leguminosae & Jengkol & Leave & Toothache & 0.18 \\
\hline Artocarpus altilis & Moraceae & Breadfruit, Sukun & Leave & Fever & 0.13 \\
\hline Averrhoa bilimbi & Oxalidaceae & Bilimbi, Belimbing Wuluh & $\begin{array}{l}\text { Leave } \\
\text { Fruit }\end{array}$ & $\begin{array}{l}\text { Fever, itches, boils, and cough } \\
\text { Pimples and cough }\end{array}$ & 0.88 \\
\hline Dillenia indica & Dilleniaceae & Simpoh, Simpur & Fruit & Coughs & 0.13 \\
\hline Flacourtia rukam & Flacourtiaceae & Rukam & Fruit & Diarrhea & 0.18 \\
\hline Leea rubra & Leeaceae & Red Tree-Vine & $\begin{array}{l}\text { Leave } \\
\text { Fruit }\end{array}$ & $\begin{array}{l}\text { Wounds } \\
\text { Dysentery }\end{array}$ & 0.07 \\
\hline Litsea cubeba & Lauraceae & Medang & $\begin{array}{l}\text { Root } \\
\text { Leave } \\
\text { Fruit }\end{array}$ & $\begin{array}{l}\text { Swelling and pain } \\
\text { Swelling and pain } \\
\text { Fever, coughs, and stomach-ache }\end{array}$ & 0.82 \\
\hline Mallotus philippensis & Euphorbiaceae & Balek angin & $\begin{array}{l}\text { Leave } \\
\text { Fruit }\end{array}$ & $\begin{array}{l}\text { Diarrhea } \\
\text { Anthelmintic }\end{array}$ & 0.09 \\
\hline Garcinia mangostana & Clusiaceae & Mangosteen, Manggis & $\begin{array}{l}\text { Bark } \\
\text { Fruit }\end{array}$ & $\begin{array}{l}\text { Diarrhea and dysentery } \\
\text { Diarrhea, dysentery and maintain digestive health }\end{array}$ & 0.57 \\
\hline Garcinia xanthochymus & Clusiaceae & Asam gelugur & Fruit & Fever and stomach problems & 0.52 \\
\hline Passiflora foetida & Passifloraceae & $\begin{array}{l}\text { Goat-Scented Passionflower, } \\
\text { Rambusa }\end{array}$ & Fruit & Children's anthelmintic & 0.10 \\
\hline Physalis minima & Solanaceae & Sunberry, Ciplukan & $\begin{array}{l}\text { Leaves } \\
\text { Fruit }\end{array}$ & $\begin{array}{l}\text { Boils } \\
\text { Bleeding gums, boils, and heartburn }\end{array}$ & 0.40 \\
\hline Psidium guajava & Myrtaceae & Guava, Jambu biji & $\begin{array}{l}\text { Leave } \\
\text { Fruit }\end{array}$ & $\begin{array}{l}\text { Cough and diarrhea } \\
\text { Dengue fever }\end{array}$ & 0.58 \\
\hline
\end{tabular}


Table 5. Economics value of indigenous fruit plants

\begin{tabular}{lccr}
\hline Botanical name & Traded & $\begin{array}{c}\text { Quantity } \\
\text { parts }\end{array}$ & $\begin{array}{c}\text { Market } \\
\text { Price } \\
\text { (IDR) }\end{array}$ \\
\hline Aleurites moluccana & Fruit & $200 \pm 1.21$ & 20,000 \\
Annona muricata & Fruit & $150 \pm 0.65$ & 3,000 \\
Archidendron jiringa & Fruit & $200 \pm 1.53$ & 5,000 \\
Artocarpus integer & Fruit & $500 \pm 1.53$ & 5,000 \\
Averrhoa bilimbi & Fruit & $200 \pm 0.93$ & 8,000 \\
Averrhoa carambola & Fruit & $100 \pm 0.93$ & 6,000 \\
Baccaurea brevipes & Fruit & $20 \pm 1.06$ & 5,000 \\
Baccaurea macrophylla & Fruit & $10 \pm 0.91$ & 5,000 \\
Baccaurea lanceolata & Fruit & $10 \pm 0.18$ & 5,000 \\
Baccaurea motleyana & Fruit & $100 \pm 0.91$ & 8,000 \\
Baccaurea polyneura & Fruit & $150 \pm 1.18$ & 12,000 \\
Citrus aurantifolia & Fruit & $150 \pm 1.05$ & 7,000 \\
Citrus maxima & Fruit & $50 \pm 0.03$ & 8,000 \\
Dimocarpus longan & Fruit & $200 \pm 0.03$ & 8,000 \\
Durio oxleyanus & Fruit & $50 \pm 0.03$ & 8,000 \\
Durio zibethinus & Fruit & $750 \pm 0.13$ & 15,000 \\
Flacourtia rukam & Fruit & $50 \pm 1.20$ & 3,000 \\
Garcinia mangostana & Fruit & $500 \pm 1.06$ & 10,000 \\
Garcinia parvifolia & Fruit & $50 \pm 1.22$ & 5,000 \\
Garcinia xanthochymus & Fruit & $500 \pm 0.13$ & 12,000 \\
Lansium parasiticum & Fruit & $500 \pm 0.80$ & 8,000 \\
Mangifera caesia & Fruit & $150 \pm 1.11$ & 8,000 \\
Mangifera foetida & Fruit & $250 \pm 1.05$ & 8,000 \\
Mangifera indica & Fruit & $350 \pm 0.88$ & 10,000 \\
Mangifera odorata & Fruit & $250 \pm 0.87$ & 8,000 \\
Manilkara zapota & Fruit & $150 \pm 1.12$ & 7,000 \\
Myristica fragrans & Fruit & $500 \pm 1.08$ & 17,000 \\
Nephelium lappaceum & Fruit & $150 \pm 0.33$ & 8,000 \\
Psidium guajava & Fruit & $250 \pm 0.56$ & 5,000 \\
Syzygium aqueum & Fruit & $350 \pm 0.33$ & 7,000 \\
Syzygium samarangense & Fruit & $250 \pm 0.23$ & 6,000 \\
\hline & & & \\
& & & \\
& & & \\
& & & \\
& & & \\
& & & \\
& &
\end{tabular}

The locals also tend to use certain parts of edible fruit plants to support some daily living requirements, especially as medicine, construction materials, firewood, furniture, forages, craft, and cash offers (Motlhanka et al. 2008). Conversely, out of all species recorded, $8.6 \%$ ad $39.3 \%$ were respectively traded for timber and firewood on the local market. Also, Mempening (L. wallichianus) was identified as another economically important and marketable species. Generally, the income obtained from the sale of wild plant species is particularly significant to low-income households that ought to improve food production with cash, in order to satisfy fundamental needs.

\section{Threats of indigenous fruit plants}

Indigenous edible fruit plants, especially the wild varieties are threatened in their natural habitat by various human activities, including agricultural expansion, fire, fuelwood collection, and selective harvesting (Table 6). These events have led to numerous losses.

As a result, agricultural activities and fire were ranked first and second, followed by fuelwood collecting and selective harvesting were ranked third and fourth, respectively. This study similar to the report by Balemie and Kebebew (2006) and Amente (2017), has shown that agricultural expansion is the main threat to wild plant species. This has significantly affected many species of wild fruit, leading to a decline in the tree and subsequent overgrowth of newly-grown plant parts of the woody species.

\section{Conservation strategies of indigenous fruit plants}

Indigenous fruits like $B$. polyneura, $F$. rukam, $G$. bancana, and G. ferrea are underutilized in the South Aceh region. These fruits may be precious are not only sources of food and nutrients to the local communities, but could moreover obtain a means of income generation. Underutilize fruit resources can be used to combat malnutrition, hunger and reduce the impact on overexploited fruits. The use of forest food plants like fruit plants that can contribute to food self-sufficiency could be one of the ways to combat food insecurity (Belem et al. (1996). Underestimation, underutilization and high population growth leading to deforestation must lead to the loss of diversity of wild fruit species (Ohiokpehai 2003; Bagra et al. 2006). In contrast, they have been exploited from the wild without any initiative to propagate them (Ondachi 1999). Furthermore, the sustainable management of these resources for the well being of the local communities and the conservation of biodiversity is of considerable importance and could equally contribute to the preservation of genetic diversity.

Table 6. Ranking of factors threats to indigenous edible fruit plants

\begin{tabular}{|c|c|c|c|c|c|c|c|c|}
\hline \multirow[b]{2}{*}{ Factor } & \multicolumn{6}{|c|}{ Average Score } & \multirow[b]{2}{*}{ Total } & \multirow[b]{2}{*}{ Rank } \\
\hline & $\begin{array}{c}\text { Pasi } \\
\text { Lembang }\end{array}$ & $\begin{array}{c}\text { Ujung } \\
\text { Pandang }\end{array}$ & $\begin{array}{c}\text { Rantau } \\
\text { Binuang }\end{array}$ & Koto & $\begin{array}{c}\text { Lawe } \\
\text { Melang }\end{array}$ & Malaka & & \\
\hline Agricultural expansion & 3.6 & 3.7 & 3.2 & 3.3 & 3.0 & 3.8 & 20.6 & 1 \\
\hline Fire & 2.8 & 2.6 & 2.7 & 2.6 & 2.8 & 2.1 & 15.6 & 2 \\
\hline Fuel wood collection & 1.2 & 1.2 & 1.4 & 1.3 & 1.2 & 1.3 & 7.6 & 4 \\
\hline Selective harvesting & 1.5 & 1.3 & 1.4 & 1.6 & 1.4 & 1.3 & 8.5 & 3 \\
\hline
\end{tabular}


Traditional knowledge can be used as a means for insitu conservation (conservation in native habitats) efforts. There are several customary rules for people in Aceh, including local communities in South Aceh region, that have existed since ancient times. Throughout the study, the older people claimed that they already have rules on forest management as agricultural land. Land clearing must always pay attention to environmental aspects hence as not to possess a negative impact on the community. Local wisdom is also reflected in the prohibition of cutting trees within a radius of $200 \mathrm{~m}$ from the edge of the spring and left and right of the river in the swampy region, $100 \mathrm{~m}$ from the river banks and $50 \mathrm{~m}$ from the edge of the tributary. In Acehnese customs, there are restrictions on access to the forest or prohibited days usually associated with "religious days". It is also prohibited to cut fruit trees when agricultural fields are opened as a food source for animals. They assume that sufficient food for animals in the forest can prevent their crop damage, particularly due to animal disturbances. This local wisdom can conserve wild plants, including indigenous fruit plants, from extinct. Traditional knowledge on the conservation of indigenous plants in the South Aceh region has been passed down from the ancestors through generations, and the results show variation in the use of wild plants from one respondent to another. Furthermore, those aged > 55 years were much more knowledgeable about species and uses than other age groups, resulting from better practical experience, especially for the wild varieties. The elders to be the custodians of knowledge and transfer it to ensure it is not lost through generations (Van der Hoeven et al. 2013).

Promoting and domesticating fruit plant species may be used for ex-situ conservation (conservation outside native habitat) efforts. Throughout this way, they can also make a significant contribution to the conservation of the environment by stopping uncontrolled harvesting from the wild and helping to conserve the various species in their native habitats where they are most effective. Promoting and domesticating wild fruit species will not only improve the nutritional status and livelihoods of local communities but will also protect them from the loss of wildlife and environmental well-being (Ohiokpehai 2003; Rathore 2009). They can integrate indigenous fruit plants with an agroforestry concept on their orchid, home garden or farmland. The integration of trees on farmland is considered to have a positive impact on the physical and chemical components of the soil, thus protecting the farm from erosion, enhancing the microclimate and also providing fuelwood, charcoal and building materials for the farmer (Fadl and Gebauer 2004). The concept of ex-situ conservation has also been applied in different regions of Indonesia, such as the conservation of Kedawung (Parkia timoriana) in the Meru Betiri National Park (Zuhud 2007), the management of the Kemiri forest (Aleurites moluccana) in Maros District (Suprayitno 2011) and the ex-situ conservation of Damar Mata Kucing (Shorea javanica) in the form of community forests in Lampung (Pramono 2000). This type of conservation, alongside the conservation of indigenous fruit plants, can also provide economic benefits for local people in rural areas.

\section{ACKNOWLEDGEMENTS}

We are grateful to all people in the studied villages for their kind hospitality and share of knowledge. We also are grateful to the Directorate General of the Ministry of Research, Technology and Higher Education for Collaborative Research Grant.

\section{REFERENCES}

Abbasi AM, Khan MA, Zafar M. 2013. Ethno-medicinal assessment of some selected wild edible fruits and vegetables of lesser-Himalayas, Pakistan. Pak J Bot 45 (SI): 215-222.

Alexiades MN, Sheldon JW. 1996. Selected Guidelines for Ethnobotanical Research: A Field Manual. The New York Botanical Garden Press, New York.

Amente DA. 2017. Ethnobotanical survey of wild edible plants and their contribution for food security used by Gumuz People in Kamash Woreda, Benishangul Gumuz Regional State, Ethiopia. J Food Nutr Sci 5 (6): 217-224.

Aryal KP, Poudel S, Chaudhary RP, Chattri N, Chaudhary P, Ning W, Kotru R. 2018. Diversity and use of wild and non cultivated edible plants in the Western Himalaya. J Ethnobiol Ethnomed 14: 10.

Bagra G, De LC, Singh VB. 2006. Collection and evaluation of some indigenous lesser-known fruits of Arunachal Pradesh. Horticulture for Sustainable Income and Environmental Protection 1: 224231.

Balemie K, Kebebew F. 2006. Ethnobotanical study of wild edible plants in Derashe and Kucha Districts, South Ethiopia. J Ethnobiol Ethnomed 2:53.

Begossi A, Hanazaki N, Tamashiro JY. 2002. Medicinal plants in the Atlantic Forest (Brazil): Knowledge, use, and conservation. Hum Ecol 30:281-299.

Belem OM, Bougnounou O, Ouédraogo SJ, Maiga AA. 1996. Les ligneux à usages multiples dans les jachères et les champs du Plateau Central du Burkina Faso. In Biodiversité, Friches et jachères. J d'Agric Trad et de Bota Appl 38 (1): 251-272.

Bunawan H, Dusik L. 2013. Botany, traditional uses, phytochemistry and pharmacology of Archidendron jiringa: A Review. Global J Pharmacol 7 (4): 474-478.

Cornara L, La Rocca A, Terrizzano L, Dente F, Mariotti MG. 2014. Ethnobotanical and phytomedical knowledge in the North-Western Ligurian Alps. J Ethnopharmacol 155 (1): 463-84.

Deb CR, Jamir NS, Ozukum S. 2013. A study on the survey and documentation of underutilized crops of three district of Nagaland, India. Global J Biosci 2: 67-70.

Dwiprabowo H. 2010. Study of policy on firewood as source of energy in Rural Areas In Java. Jurnal Analisis Kebijakan Kehutanan 7 (1): 1-11.

Fadl KEM, Gebauer J. 2004. Crop performance and yield of Groundnut, Sesame and Roselle in agroforestry cropping system with Acacia Senegal in North Kordofan (Sudan). J Agr Rural Dev Trop 105 (2): $149-154$.

FAO. 1999. Use and potential of wild plants, information division and food and agricultural organization of the united nation. Rome, Italy.

Giday M, Asfaw Z, Woldu Z. 2009. Medicinal plants of the Meinit ethnic group of Ethiopia: An ethnobotanical study. J Ethnopharmacol 124: 513-521.

Gunawan, Chikmawati T, Sobir, Sulistijorini. 2016. Review: Fitokimia genus Baccaurea spp. Bioeksperimen 2 (2): 96-110. [Indonesia]

Handayani T. 2018. Diversity, potential and conservation of Annonaceae in Bogor Botanic Gardens, Indonesia. Biodiversitas 19 (2): 591-603.

Hazarika TK, Lalramchuana, Nautiyal BP. 2012. Studies on wild edible fruits of Mizoram, India used as ethnomedicine. Genet Resour Crop Evol 59: 1767-1776.

Ismaini L, Lailati M, Rustandi, Sunandar D. 2015. Composition and plant diversity analysis on Mount Dempo, South Sumatra. Pros Sem Nas Masy Biodiv Indon 1 (6): 1397-1402.

Johns T, Mohoro EB, Sanaya P. 1996. Food plants and masticants of the Batemi of Ngorongoro District, Tanzania. Econ Bot 50: 115-121.

Katewa SS. 2003. Contribution of some wild food plant from the forestry to the diet of tribals of southern Rajasthan. Indian Forester 129: 11171131 
Khruomo N, Deb CR. 2018. Indigenous wild edible fruits: Sustainable resources for food, medicine and income generation, a study from Nagaland, India. J Exp Biol Agric Sci 6 (2): 405-413.

Li F, Zhuo J, Bo L, Jarvis D, Long C. 2015. Ethnobotanical study on wild plants used by Lhoba people in Milin Country, Tibet. J Ethnobiol Ethnomed 11: 23.

Mabaya E, Jackson J, Ruethling G, Carter CM, Castle J. 2014. Wild fruits of Africa: Commercializing natural products to improve rural livelihoods in southern Africa. Intl Food Agribus Man 17: 69-74.

Miranda TM, Hanazaki N, Govone JS. 2011. Existe utilização efetiva dos recursos vegetais conhecidos em comunidades caiçaras da ilha do Cardoso, Estado de São Paulo, Brasil? Rodriguésia 62:153-169.

Mohanty M, Pradhan C. 2015. A Review on phytochemistry, bio-efficacy, medicinal and ethno-pharmaceutical importance of Artocarpus altilis. IJPPR Human J 3 (1): 219-231.

Mojeremane W, Tshwenyane SO. 2004. Azanza garckeana: A valuable edible indigenous fruit tree of Bostwana. Pak J Nutr 3: 264-267.

Motlhanka DMT, Motlhanka P, Selebatso T. 2008. Edible indigenous wild fruit plants of Eastern Bostwana. Intl J Poultry Sci 7 (5): 457-460.

Munawaroh E, Saparita R, Purwanto Y. 2011. Community dependence on non-timber forest products in Malinau, East Kalimantan: An ethnobotany analysis and its implications for forest conservation. Berkala Penelitian Hayati 7A: 51-58.

Muok BO, Owuor B, Dawson I, Were J. 2001. The potential of indigenous fruit trees, result of a study in Kitui District, Kenya. Agroforestry Today 12: 13-15.

Murmu P, Kumar S, Patra JK, Singh NR, Rath SK. 2016. Ethnobotanical, nutritional, phytochemical and antimicrobial studies of Garcinia xanthochymus fruit extracts. British Biotech J 13 (2): 1-11.

Mwema CM, Mutai BK, Lagat JK, Kibet LK, Maina MC. 2012 Contribution of selected indigenous fruits on household income and food security in Mwingi, Kenya. Curr Res J Soc Sci 4 (6): 425-430.

Navia ZI, Chikmawati T. 2015. Durio tanjungpurensis (Malvaceae), a new species and its one new variety from West Kalimantan, Indonesia. Bangladesh J Bot 44 (3): 429-436.

Ohiokpehai O. 2003. Promoting the nutritional goodness of traditional food products. Pak J Nutrition 2: 267-270.

Ondachi PW. 1999. Nutritional studies of indigenous fruit trees in support of conservation. Annual Research Report, part 1. African Academy of Sciences, Nairobi.

Ong HC, Norliah A, Sorayya M. 2012. Traditional knowledge and usage of edible plants among the Temuan villagers in Kampung Tering, Kuala Pilah, Negeri Sembilan, Malaysia. Indian J Tradit Know 11 (1) 161-165.

Pedraza-Chaverri J, Cárdenas-Rodríguez N, Orozco-Ibarra M, PérezRojas JM. 2008. Medicinal properties of mangosteen (Garcinia mangostana). Food Chem Toxicol 46: 3227-3239.

Pilgrim SE, Cullen LC, Smith DJ, Pretty J. 2008. Ecological knowledge is lost in wealthier communities and countries. Environ Sci Technol 42 . 1004-1009.

Poderoso RA, Hanazaki N, Junior AD. 2012. How is local knowledge about plants distributed among residents near a protect area? Ethnobiol Conserv 1 (8): 1-26.

Prabhu S, Vijayakumar S, Yabesh JE, Ravichandran K, Sakthivel B. 2014 Documentation and quantitative analysis of the local on medicinal plants in Kalrayan hills of Villupuram district, Tamil Nadu, India. J Ethnopharmacol 157: 7-20.

Pramono H. 2000. Community Dependence on Repong Damar on the Krui Coast of West Lampung. [Thesis]. Bogor Agricultural University, Bogor. [Indonesian]

Quinlan MB, Quinlan RJ. 2007. Modernization and medicinal plan knowledge in a Caribbean horticultural village. Med Anthropol 21 (2): 169-192

Rahmawati M, Hayati E. 2013. Classification is based on the character of vegetative morphology in the germplasm of bananas from Aceh Besar regency. Jurnal Agrista 17 (3): 111-118.

Rana D, Bhatt A, Lal B. 2019. Ethnobotanical knowledge among the semi-pastoral Gujjar tribe in the high altitude (Adhwari's) of Churah Subdivision, District Chamba, Western Himalaya. J Ethnobiol Ethnomed 15: 10.

Rathore M. 2009. Nutrient content of important fruit trees from arid zone of Rajasthan. J Hortic Fores 1: 103-108.

Roos MC, Kebler PJA, Gradstein R, Baas P. 2004. Species diversity and endemism of five major Malesian island: Diversity-area relationships. J Biogeogr 31: 1893-1908
Saka J, Msothi JD, Maghembe JA. 1994. The nutritional value of edible fruits of indigenous wild trees of Malawi. Forest Ecol Manag 64: 245248.

Sanjayrao KS, Sanjay GV. 2019. Studies on Ethnobotanical plants used by tribal community of Nashik District, Maharashtra, India. J Med Plants Stud 7 (4): 200-202.

Saynes-Váquez A, Vibrans H, Vergara-Silva F, Caballero J. 2016. Intracultural differences in local botanical knowledge and knowledge loss among the Mexican Isthmus Zapotecs. PLoS ONE 11 (3): e0151693. DOI: 10.1371/journal.pone.0151693.

Silalahi M, Supriatna J, Walujo EB, Nisyawati. 2015. Local knowledge of medicinal plants in sub-ethnic Batak Simalungun of North Sumatra, Indonesia. Biodiversitas 16 (1): 44-54.

Silalahi M, Nisyawati, Anggraeni R. 2018. Ethnobotany study of the edible plants noncultivated By Batak Toba Sub-ethnic in Peadungdung Village, North Sumatra, Indonesia. Jurnal Pengelolaan Sumberdaya Alam dan Lingkungan 8 (2): 241-250.

Sousa RS, Hanazaki N, Lopes JB, de Barros RFM. 2012. Are gender and age important in understanding the distribution of local botanical knowledge in fishing communities of the Parnaíba Delta Environmental Protection Area? Ethnobot Res Appl 10: 551-559.

Sundriyal M, Sundriyal RC, Sharma E, Porohit AN. 1998. Wild edible and other useful plants from the Sikkim Himalaya, India. Oecologia Montana 7: 43-54

Suprayitno AR. 2011. The Model of Increasing Participation of Farmers Around the Forest in Managing the People's Candlenut Forest (Case of Management of the Candlenut Forest in the Bulusaraung Mountain Area, Maros Regency, South Sulawesi Province). [Thesis]. Bogor Agricultural University, Bogor. [Indonesian]

Suwardi AB, Indriaty, Navia ZI. 2018. Nutritional evaluation of some wild edible tuberous plants as an alternative foods. Innovare J Food Sci 6 (2): 9-12.

Suwardi AB, Navia ZI, Harmawan T, Syamsuardi, Mukhtar E. 2019a. Sensory evaluation of mangoes grown in Aceh Tamiang District, Aceh, Indonesia. Adv Ecol Environ Res 4(3): 79-85.

Suwardi AB, Navia ZI, Harmawan T, Syamsuardi, Mukhtar E. 2019b. The diversity of wild edible fruit plants and traditional knowledge in West Aceh region, Indonesia. J Med Plants Stud 7 (4): 285-290.

Suwardi AB, Navia ZI, Harmawan T, Syamsuardi, Mukhtar E. 2020. Ethnobotany, nutritional composition and sensory evaluation of Garcinia from Aceh, Indonesia. Mater Sci Eng 725 (1): 012064.

Tardiõ J, Pardo-de-Santayana M. 2008. Cultural importance indices: a comparative analysis based on the useful wild plants of Southern Cantabria (Northern Spain). Econ Bot 62: 24-39.

Uji T. 2004. Species diversity, germplasm, and potential of Borneo indigenous fruits. BioSMART 6 (2): 117-125.

Ullah M, Khan UM, Mahmood A, Hussain M, Wazir MS, Daud M, Shinwari Z. 2013. An ethnobotanical survey of indigenous medicinal plants in Wana distrist, south Waziristan regency, Pakistan. J Ethnopharmacol 150: 918-924.

Van der Hoeven M, Osei J, Greeff M, Kruger A, Faber M, Smuts CM. 2013. Indigenous and traditional plants: South African parents' knowledge, perceptions and uses and their children's sensory acceptance. J Ethnobiol Ethnomed 9: 78. DOI: 10.1186/1746-4269-978.

Vijayakumar S, Yabesh JE, Phrabu S, Manikandran R, Muralidharan B. 2015. Quantitaive ethnomedicinal study of plants used in the Nelliyampathy hills of Kerala, India. J Ethnopharmacol 161: 238-254.

Watson BJ. 1984. Rambutan. In: Page PE (ed.). Tropical tree fruits for Australia. Queensland Department of Primary Industries. Horticulture Branch, Brisbane.

Whitten T, Damanik SJ, Anwar J, Hisyam N. 1997. The Ecology of Sumatra. Periplus Editions (HK) Ltd., Singapore.

Winarno. 2000. Government policy in the development of Indonesian horticulture. Proceedings of the Day Seminar. Puspa Love Day and National Animal. Explores the potential and enhances the prospects of horticultural crops towards food security. Plant Conservation Center, Kebun Raya Bogor, Bogor.

Wiryono, Japriyanto, Erniwati. 2017. The diversity of locally utilized plants and local botanical knowledge in Central Bengkulu District, Bengkulu Province, Indonesia. Biodiversitas 18 (4): 1589-1595.

Yabesh JE, Phrabhu S, Vijayakumar S. 2014. An ethnobotanical study of medicinal plants used by traditional healers in silent valley of Kerala, India. J Ethnopharmacol 154: 774-789. 
Yap SK, Martawijaya A, Miller RB, Lemmens RHMJ. 1995. Durio Adans. In: Lemmens RHMJ, Soerianegara I, Wong WC (eds.). Plant Resources of South-East Asia 5 (2): Timber trees: Minor commercial timbers. Prosea Foundation, Bogor.
Zuhud EAM. 2007. Community Attitudes and Conservation, an Analysis of Kedawung (Parkia timoriana (DC) Merr.), as a Stimulus of Medicinal Plants for the Community, Cases in Meru Betiri National Park. [Dissertation]. Bogor Agricultural University, Bogor. [Indonesian] 